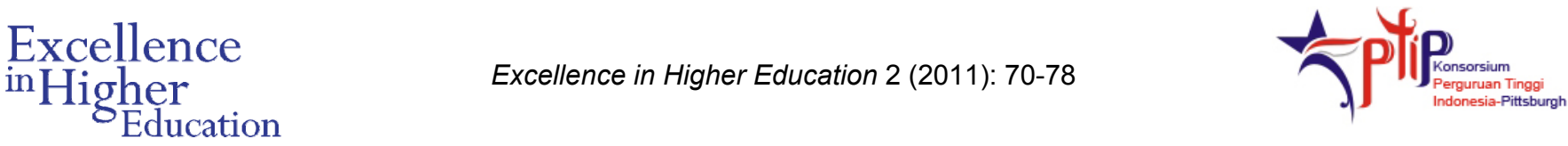

\title{
Action Research on the Implementation of Active Learning at an Elementary School in Aceh
}

\author{
Syamsul Bahri Ys,,${ }^{\mathrm{a}}{ }^{\mathrm{a}}$ M. Nasir Mara, ${ }^{\mathrm{a}}$ M. Yamin, ${ }^{\mathrm{a}}$ Suid A. B., ${ }^{\mathrm{a}}$ and Cut Nya Dhin ${ }^{\mathrm{b}}$ \\ ${ }^{a}$ Syiah Kuala University, Indonesia \\ ${ }^{\mathrm{b}}$ University of Muhammadiyah Aceh, Batoh, Banda Aceh, Indonesia
}

\begin{abstract}
Teachers in the state elementary schools and state Islamic elementary schools of the Indonesian province of Aceh have been trained repeatedly over the past several years on a variety of educational reform initiatives. One of the most important of these has been the effort to promote teaching for active learning in Acehnese schools. Research in other countries, and past experience with teacher training efforts in Aceh, suggest that such a transformation in classroom practice will not be easy. In order to investigate whether and how teachers were transferring their training in active learning into actual classroom practice, a team of lecturers from three universities in Banda Aceh conducted an action research project in one state elementary school. We found that teachers', principals', and school supervisors' understanding of teaching for active learning remained extremely tentative months after receiving training in active learning, and their tentative understanding prevented their active experimentation with what they had learned. A brief retraining session focused on arriving at a common understanding of the concept, committed school leadership, and learning from peers appeared to have a significant impact on teachers' willingness and ability to try to teach for active learning.
\end{abstract}

\begin{abstract}
Abstrak
Para guru di beberapa sekolah dasar negeri dan madrasah ibtidaiyah negeri di propinsi Aceh mendapat serangkaian pelatihan tentang berbagai inisiatif perubahan pendidikan, selama beberapa tahun belakangan. Salah satu yang terpenting adalah upaya mengembangkan pengajaran active learning di sekolah-sekolah di Aceh. Beberapa riset di negara lain menengarai, dan juga merujuk pada pengalaman pelatihan guru di Aceh sebelumnya, bahwa perubahan praktek pengajaran di kelas tidaklah mudah. Untuk meneliti apakah guru dan bagaimana guru mentrasfer pelatihan mereka ke dalam praktek pengajaran kelas, tim dosen dari tiga universitas di Banda Aceh mengadakan penelitian tindakan di satu sekolah dasar. Tim menemukan, bahwa pemahaman terhadap pengajaran active learning para guru, kepala sekolah dan pengawas sekolah masih sangat tentatif setelah menerima pelatihan active learning beberapa bulan, dan pemahaman tentatif ini cenderung membatasi mereka untuk bereksperimen dengan ilmu yang sudah mereka pelajari. Adanya sesi pelatihan pendek dengan fokus membangun pemahaman konsep yang sama, kepemimpinan sekolah yang berkomitmen, dan upaya belajar dari sesama rekan guru nampaknya dapat membuahkan pengaruh yang signifikan terhadap kesediaan dan kecakapan guru untuk mencoba mengajar dengan strategi active learning.
\end{abstract}

Key Words: Active Learning, Action Research, Aceh, Elementary Schools

\section{Introduction}

Indonesia is a sprawling tropical archipelago in Southeast Asia consisting of more than 17,000 islands and 33 provinces with a population in excess of 237 million people (Digital Media Across

*Corresponding author. Address: Faculty of Education, Syiah Kuala University, Banda Aceh, Indonesia.

Email: syb_ina@yahoo.com.
Asia 2011). It is the largest Muslim country in the world as well as the fourth largest country overall. Its educational system is administered by the Ministry of National Education (MONE) and the Ministry of Religious Affairs from the capital city of Jakarta through provincial and district education offices throughout the country. The system offers comprehensive education for Indonesian students from preschool/kindergarten (ages 1-6) to elementary school (ages 6-11), junior secondary (ages 11-13) and senior high school (ages 14-16). And Indonesia's more than 3,000 
institutions of higher education offer both undergraduate and graduate degrees, including the doctorate (Nation Master 2011).

Though Indonesia boasts a comprehensive system of education and has achieved near universal access to basic education (UNICEF n.d.), it still lags far behind its neighbors in Southeast Asia in terms of the quality of that education. For instance, in 2005 the United Nations Development Program's (UNDP) Human Development Index, which includes education in its calculations, ranked Indonesia 110th, under Vietnam (108), Thailand (73), Malaysia (61) and Singapore (25) (UNDP Philippines 2005). Furthermore, the Trends in International Mathematics and Science Study (TIMSS) ranked Indonesia 34th in mathematics under Thailand (27), Malaysia (16), and Singapore (1) and 32nd in natural sciences under Thailand (24), Malaysia (21), and Singapore (2) (Mullis, Martin, Gonzales, and Chrostowski 2003). Literacy rates in Indonesia also lag behind its neighbors, with Thailand (32) and Hong Kong (6) ranked well above Indonesia at 39th (Index Mundi 2011). Despite these poor international comparisons though, individual Indonesian students routinely perform well in international competitions. This paradox of selected individual excellence and poor international comparisons of general academic achievement highlight the promise and the challenge of Indonesian education: the country must do more to ensure that the educational system does a better job of developing the intelligence, creativity and talent that lies latent in the Indonesian people.

This crossroads of educational development for Indonesia challenges both education officials and researchers to take bold steps in reforming Indonesian education. An important step in that direction was taken in 2003 with the passage of Act No. 20, calling for the decentralization of educational decision making from Jakarta to the provinces and districts (Bjork 2003), and Government Regulation No. 19 of 2005 which decentralized authority over curricular matters to local authorities as long as they continued to meet nationally established standards (Setiawan 2009). For the province of Aceh, located at the extreme western end of the Indonesian archipelago, these changes have meant a level of autonomy in educational decision-making unprecedented in its history.

One indication of Aceh's educational autonomy is the degree to which the curricula of schools under the authority of MONE incorporate Islamic studies, a reflection of the fact that Aceh is the only province in Indonesia that has implemented Islamic law (Kingsbury 2006). Other than this, however, Aceh is not obviously different from the rest of Indonesian education in terms of the challenges it faces. Access to education, for instance, remains a problem for some, particularly those residing in poor, remote areas of the province where poverty, geographical conditions and inadequate infrastructure limit access to schools.

Quality of instruction is another problem. While the overall numbers of teachers in Aceh may be adequate, there is a shortage of well trained teachers. Teacher assessments have shown that many teachers' competence falls below acceptable levels. Many tests show that the teachers' competence is still far from standard. Most teachers still lecture students on the traditional curriculum, unable to take advantage of new policies that give them the freedom to develop curricula more relevant to the social contexts of their pupils. Until recently, the curriculum was prepared entirely by the MONE; teachers simply transmitted what was delivered to them to their students. Current policy, however, expects schools to develop their own curricula that reflect the needs and interests of their own communities and meets nationally established achievement benchmarks. While some schools have been able to meet the expectations of this policy, many have not.

The supply of teachers is another problem for education in Aceh. The teacher-student ration in Aceh is 1 to 20, which compares favorably with China and Thailand (1 to 21), Singapore and Vietnam (1 to 25 ), South Korea (1 to 31 ) and the Philippines (1 to 35$)$; however, teachers are not distributed uniformly across the province (Huebler 2008; Australia-Indonesia Basic Education Program 2010). In urban areas there is a sufficient supply of teachers, perhaps even more than is needed. But in rural areas teachers are in much shorter supply. In some remote areas, only one or two teachers are available for each school. The imbalance in numbers of teachers between urban and rural schools is partly due to teacher transfer from rural schools to urban schools. When teachers are hired as civil servants they agree to teach in rural schools, but once they have been working for several years they commonly put some effort into transferring to urban schools. Therefore, although more teachers are recruited, rural schools always have insufficient teachers. While teachers do from time to time transfer from urban to rural schools, most consider it a punishment that they would like to avoid.

\section{Improving Education in Aceh through Action Research and Active Learning}

Developing the capacity of teachers to teach more effectively can be accomplished in a variety of ways. We can raise the academic and professional requirements necessary to become or remain a teacher, as was accomplished in the 2005 Teachers and Lecturers Act, which requires all teachers to hold or obtain a fouryear undergraduate degree by 2015 (Setiawan 2009). We can also provide in-service training designed to help teachers in the field improve their knowledge and skills, a strategy adopted by the 
United States Agency for International Development through its Decentralized Basic Education 2 (DBE2) project implemented in Aceh and seven other provinces (Education Development Center [EDC] 2011). We can also equip teachers with the skills they need to solve teaching and nonteaching problems professionally through controlled action research. This is one of the strategies educational officials have taken to enhance the skills of teachers in Aceh in recent years.

Action research is a form of inquiry that has been found useful in a variety of settings from working with homeless women (Clover 2011) to helping engineering students develop a sense of responsibility for their community (Chen, Wang, Chen, and Liao 2011) to reducing smoking among young adults (Mendenhall, Harper, Stephenson, and Haas 2010) to developing community pharmacy teams (Ngwerume and Themessl-Huber 2010). Moreover, it is a form of inquiry accessible to individuals without extensive training in more advanced research methodologies, yet robust enough to provide real insight into problems and contribute to theory. Thus it has been used widely in the professional development of teachers in many different countries (Postholm 2010; Halai 2011; López-Pastor, Monjas, and Manrique 2011). According to Stringer $(2007,1)$, action research is

A systematic approach to investigation that enables people to find effective solutions to problems they confront in their everyday lives. Unlike traditional experimental/scientific research that looks for generalizable explanations that might be applied to all contexts, action research focuses on specific situations and localized solutions. Action research provides the means by which people in schools, business and community organizations ... may increase the effectiveness of the work in which they are engaged.

Though action research can be and is conducted in a wide variety of fields, it is perhaps most common in education, particularly in the form of classroom action research (CAR) (Stringer 2007) where it constitutes a useful professional development strategy because it envisions teachers as researchers, as agents of change working in collaborative relationships with other stakeholders. Using CAR, teachers can systematically assess problems in the classroom and come up with evidence-based strategies for resolving them.

In the past in Aceh, efforts to improve the ability of teachers and lecturers to conduct research used a research development dissemination approach. This approach emphasized a top down research planning process as well as a clear theoretical orientation. This paradigm, however, is no longer considered appropriate in the context of school-based quality management that has emerged in the process of decentralization. The shift away from centralized authority, whether in the MONE or in the classroom, requires development of the capacity to effectively exercise that newly acquired autonomy, thus the emphasis on action research and active learning in recent Indonesian educational reforms.

Teaching for active learning has been one other professional development strategy encouraged in Aceh over the past decade. Studied and discussed in one form or another for centuries, teaching for active learning starts as a rejection of traditional models of teaching in which knowledge is presumably transmitted from teacher or text to student (Rousseau 1762/1990; Dewey 1938; Bolhuis and Voeten 2001). Instead, drawing upon the constructivist learning theory of Vygotsky and Piaget (Stern and Huber 1997), active learning envisions the learner as an active participant in his or her own learning, actively constructing new knowledge out of the encounter between the learner's past experiences and the learning experiences provided in the classroom or other educational setting. Though it is defined in various ways, teaching for active learning in marked by a number of key characteristics: (1) students are involved in more than listening in the classroom, (2) there is a greater emphasis on the development of skills rather than the simple transmission of information, (3) students are engaged in a variety of activities, and (4) students learn to think about the way they learn (Keyser 2000). Its essential feature, according to Hannele Niemi $(2002,764)$ is "a learner's active impact on learning and a learner's involvement in the learning process."

After years of research on the efficacy of teaching for active learning there is broad empirical support for its effectiveness in promoting student learning and retention (Woolman 2002; Prince 2004). Advocates of active learning also argue that it can promote democratic attitudes among students by helping them become active, questioning adults (Sturtevant and Linek 2007). Yetilú de Baessa, Ray Chesterfield, and Tanya Ramos (2002, 207), for instance, claim that "studies argue persuasively for a link between active, decentralized classroom environments and democratic behavior of students." They go on to argue that

For countries wishing to develop democratic behavior in primary school, decentralized classrooms that promote active learning by offering children the opportunity to engage in a variety of learning contexts, especially those of small group student interaction, appear essential. (217)

Thus teaching for active learning may also contribute to Indonesia's transition to democracy after the demise of the Suharto regime in 1998. For these reasons-both pedagogical and political - teaching for active learning is an educational reform 
that has been extensively promoted since the late 1980s to the present in countries around the world (Stern and Huber 1997; Ginsburg and Megahed 2008).

Teaching for active learning was heavily emphasized in the USAID-funded project Decentralized Basic Education. Component two of that five-year effort (2005-2010) focused on the improvement of teaching and learning in the state elementary schools (SD: sekolah dasar) and state elementary-level madrasahs (MIN: madrasah ibtidâ'iyah negeri) in eight provinces across Indonesia. All told, approximately 1,075 schools and 14,500 teachers serving as many as 231,000 students received training under DBE2 (EDC 2011). In Banda Aceh alone DBE2 worked to improve 19 schools and trained more than 500 teachers, principals, supervisors and school committee members.

The DBE2 effort in Aceh was focused on improving teachers' professional knowledge and skills in the belief that greater teacher capacity would lead to improved student achievement and better school performance. To achieve these goals the project delivered a series of three workshops that improved the learning environment of schools and introduced teachers to a more effective teaching methodology_active learning. These included a School Team Workshop for teachers, principals, supervisors, local education officials, and members of the school committees designed to introduce participants to active learning and thus build support among key stakeholders for teachers as they attempted to transition to teaching for active learning. This was followed up by Teachers' Working Group and Principals' Working Group meetings designed, in part, to provide further instruction and support for the implementation of active learning in local schools. Finally, recognizing that workshops alone would be inadequate to effectively support the implementation of active learning strategies, the project provided on-going monitoring and mentoring of schools and teachers as they worked to put what they learned into practice in their own schools.

\section{Purpose of the Study}

Based on our prior experience in teacher training in Aceh, as well as international studies that have demonstrated that transitioning to active learning strategies is difficult even in more advanced societies (Niemi 2002), we concluded that SD and MIN teachers in Aceh were likely to experience on-going difficulties in learning to teach for active learning even after the DBE2 training and monitoring. Therefore, we assembled a team of lecturers from Syiah Kuala University, the State Islamic Studies Institute, and Muhammadiyah University, all in Banda Aceh, to conduct a follow-up inquiry into the implementation of active learning in Banda Aceh schools. Since the DBE2 training involved both SDs, which are under the administrative authority of the MONE, and MINs, which are under the administrative authority of the Ministry of Religious Affairs, we decided to separate our research group into two teams, one of which would investigate the implementation of active learning in one or more SDs while the other would focus on one or more MINs. This article will report on the results of our inquiry in one SD in Banda Aceh.

The purpose of our research was to find out whether or not active learning was being implemented in elementary schools as expected. We also wanted to understand any obstacles faced by teachers in implementing active learning in their classrooms and, if necessary, provide additional support to their efforts to change the professional habits and learning environments of schools in Aceh. Specifically, we set out to address the following questions:

1. What are teachers' understandings and misunderstandings of active learning?

2. What are the teachers' perceptions of the institutional supports and barriers to doing teaching for active learning in the classroom?

3. What are the principal's perceptions of the supports and barriers to doing teaching for active learning in the school?

4. What are the school committee members' understandings and misunderstandings of active learning?

5. What are parents' understandings and misunderstandings of active learning?

\section{Research Site}

Banda Aceh is both the provincial capital and educational center of Aceh. Home to three universities, it offers a wide range of educational options, including numerous SDs and MINs. Parents can choose to send their children to either form of elementary school. For our inquiry, we selected an SD on the outskirts of Banda Aceh that had been the recipient of DBE2 training, including training in teaching for active learning. The school, which was established in 1983, is situated in a crowded neighborhood. It enrolls just under 200 students, roughly evenly divided between boys and girls, and has a teaching staff of 15 . Ten of these teachers hold civil service appointments (meaning they are national government employees with security of tenure) while the remaining five are contractual teachers (without security of tenure) (Bjork 2004). Only two of the fifteen hold undergraduate degrees. The remaining thirteen are graduates of Teacher Training Schools and/or hold a diploma equivalent to two years of postsecondary education. The majority of the teachers are in their late 40 s and older. 
The school's physical infrastructure is fairly typical of elementary schools in Aceh, with the exception of ten new restrooms donated by UNICEF. There are six classrooms, a teacher room, an administrative office, and a room designated for student activities. During the period of our research the school did not have a library to house the collection of textbooks and other books that had been donated to the school by international organizations. By the end of our inquiry, however, construction on a library had begun with funding from the central government.

\section{Methods}

Since we were not only interested in how teaching for active learning was being implemented in this school but how we might help teachers overcome any difficulties they were encountering in the effort, we designed our study as an action research project (Stringer 2007). Therefore, our project involved multiple cycles of data gathering (Kemmis and McTaggart 2000). Data was collected in each cycle from teachers and principals using semi-structured as well as informal interviews. Focus group discussions were also held with teachers. Members of the research team also conducted multiple observations of instruction, noting the instructional strategies teachers were using, students' responses, classroom environment, and the physical layout of the classroom.

Interviews and focus groups were recorded, transcribed and distributed to the members of the research team. Observational data were recorded in field notes and likewise shared with the other members of the research team. After each cycle of data collection the research team met to collaboratively analyze the data. This turned out to be a more difficult exercise than we had anticipated. At times it led to protracted debate within the research team. However, we were able to identify overlapping data gathered by more than one team member and to identify areas where we had insufficient data. In those instances a member of the research team would return to the school to gather additional data. Once we concluded data collection, the team met again to conduct both a holistic and categorical analysis of data in order to identify themes, as well as patterns within those themes, in the data.

\section{Findings}

Our analysis of the data gathered over the course of the project generated a number of interesting observations, the majority of which suggested ongoing difficulties in transferring what teachers had learned in their active learning workshops to their day-to-day classroom practices. For instance, our data suggests that teachers' understanding of teaching for active learning remains limited. In interviews, when we asked some teachers about active learning, they responded with their own questions: "PAKEM is a method, isn't it?" one teacher asked (Teacher Interview). Another asked us whether active learning is Educational Unit Level Curriculum (KTSP: Kurikulum Tingkat Satuan Pendidikan). Teachers seemed to have difficulty distinguishing among an alphabet soup of acronyms that had labeled the various reform initiatives they had been exposed to in recent years. Over time, teachers had participated in many workshops designed to promote one educational reform or another. Often, as in the case of Active, Creative, Effective and Joyful Learning (PAKEM: Pembelajaran Aktif, Kreatif, Efektif dan Menyenangkan), and even KTSP (which included active learning strategies along with local curriculum development), the focus of the training was overlapping, if not identical. We suspect the different labels, accompanied by the teachers' vague sense that this training was similar to the last one, simply confused teachers about what was and what was not active learning.

Other teachers reported that they felt they understood teaching for active learning during training sessions, but when they got back to their classrooms, they were unsure. "When I participated in the training I really understood what the active learning is, but if you ask me now I can't define what the active learning is" (Teacher Interview). Even among those teachers who felt they understood what teaching for active learning means, not all felt comfortable trying to teach for active learning in their classroom. "We understand what it is although we don't perfectly understand it, because almost all teachers have participated in training on active learning. However, not all teachers can use it in the classroom" (Teacher Interview). Much of our data indicated this sort of tentativeness about the meaning of active learning which generally translated into a reluctance to try it out themselves.

Our classroom observations bore out this finding. In one observation, for instance, we found that the teacher did not use any active learning strategies in her teaching. She stood in front of the class and delivered a lecture while the students sat in neat rows listening. The class continued in this fashion until it was dismissed. The classroom environment was unappealing and not arranged for active collaboration. The teacher's desk was arranged at the front of the room and students' desks in rows. There were few educational displays, and what few items were there were haphazardly arranged and did not appear to be used. When we asked the teacher why she chose this approach to deliver her lesson, she smiled and replied that the most important thing was that the students understood the lesson.

In focus group discussions and interviews teachers reported that supervisors from district educational offices responsible for monitoring the schools did not seem to understand teaching for active learning either. One teacher said, "I figured out that even 
some supervisors do not know about teaching for active learning" (Teacher Focus Group). Another said, "Sometimes supervisors do not expect the same model and language" (Teacher Interview). Teachers also commented on the infrequency of supervisor visits to the school: "Sometimes there are one or two supervisors, but their coming is not regular" (Teacher Focus Group). When they did come they often only checked teachers' lesson plans. But on those occasions when they did observe teachers in the classroom, they asked teachers to teach differently. "The supervisors only know what we wrote. When they checked how we taught in the classroom, they asked us to use other methods" (Teacher Focus Group). These teachers believed that supervisors should have more knowledge of active learning and that such ineffective supervision allowed teachers to avoid implementing teaching for active learning.

The principal of the school expressed a positive attitude toward teaching for active learning, noting that he provided complete support for its successful implementation in his school. He expressed his hope and expectation that all the teachers of the school would use active learning strategies for all subjects. However, he added that some teachers were not teaching for active learning and that this was a challenge for him as principal. When asked what he could do to further encourage teachers to develop active learning strategies, he was pessimistic, saying it depended upon the teachers. "Just like I said, where there is a will there is a way, and there is always a challenge for that, right? If we try to make ourselves accustomed to it, everything would be easier" (Principal Interview). The most important thing, in his estimation, was that teaching for active learning should not affect the syllabus.

When a member of the research team asked the principal whether he thought a teacher discussion group focused on teaching for active learning might be helpful, he suggested that teachers were not using active learning strategies, even though many had participated in the active learning training. We also suggested inviting instructors from outside the school to help his teachers increase their understanding and comfort with teaching for active learning. He replied, "That would be difficult. The teachers participated in the training because it is free, but they are not going to participate if it is not free. They also asked whether they would be provided a certificate before they decided to join" (Principal Interview). When asked about using the school operating fund for retraining, he indicated that he had to be very careful with those funds and seek the permission of his superiors. He was, however, open to inviting DBE2 and the members of the research team to retrain the teachers in his school.

School committee members and parents displayed a lack of awareness and interest in teaching for active learning as well. The head of the school committee had some awareness of teaching for active learning: "We used to study only by listening to our teachers' explanation, but nowadays students sit in groups and ask many questions" (School Committee Focus Group). Other members remained silent when asked about teaching for active learning in their school. However, they did suggest that teaching methods were the responsibility of the teachers and the principal, not school committee members. Parents too were largely unfamiliar with active learning. Most were farmers and traders in the market and usually only came to school to receive their children's reports. They trusted the school to educate their children. One parent, however, who happened to be a teacher herself was familiar with teaching for active learning and expressed her confidence that the teachers of this school could do it. "I am a teacher, and I believe the teachers in this school know and can implement the active learning" (Parent Interview).

Clearly, teaching for active learning had just not caught on in this school. Despite having training, neither teachers nor the principal nor supervisors claimed to have a clear understanding of teaching for active learning. The teachers we interviewed said that if they did not understand active learning, the principal did not understand it either, and that if they were not teaching for active learning, it was at least partly the fault of supervisors who were not making them. The principal said it was up to the teachers but was unwilling to use resources at his disposal to promote active learning. School committee members, perhaps correctly, believed it was not their responsibility to promote one teaching method over another, and parents did not appear to have been engaged in any effort to change the teaching culture of this school. In short, teaching for active learning did not seem to be happening in this school.

\section{Intervention}

After consulting with the other research team investigating active learning in two Banda Aceh MINs, we decided to organize a common intervention to be held at one of the two MINs researched by the madrasah research team. This school was selected because it appeared to have been quite successful in implementing teaching for active learning. According to the principal, her school was often observed by principals and teachers from other schools to see how active learning was implemented. On top of that, many visitors came from other regions and provinces. She noted that it was not easy for her teachers to learn to teach for active learning at first, but when they approached the task with a real determination to change classroom practices, they became accustomed to it. Both research teams felt that an opportunity to see how colleagues at a school similar to theirs implemented teaching for active learning would help 
teachers in the two schools struggling with active learning to try the strategy out in their own schools.

Principals and teachers from the SD reported on here (and one of the two MINs investigated by the madrasah research team) participated in a day-long workshop held at MIN Rukoh, in Banda Aceh. MIN Rukoh, which was found to have successfully implemented teaching for active learning, provided its teachers and principal as facilitators. After opening remarks from one of the DBE2 coordinators, the workshop began with a session designed to come to a common understanding of teaching for active learning. The discussion was lively, due to initially quite different conceptions of active learning, but the group eventually arrived at a consensus on active learning as an instructional strategy in which teachers functioned as facilitators rather than mere transmitters of information and instructional materials were designed to interest and engage students.

Workshop participants-principals, teachers and school committee members - were then divided into groups and assigned to classrooms where they were able to observe MIN Rukoh teachers teaching for active learning in a variety of subjects. Participants were instructed to pay attention to the teacher's and students' activities as well as the physical arrangement of the classroom, the use of instructional media, and the overall culture of the classroom. After the observations, participants were engaged in a discussion of what they had seen. The demonstrations had been so successful that some participants suspected that the lessons had been staged. The MIN Rukoh teachers, however, assured participants that what they saw was what they would see in their classrooms on any other day.

Before the end of the workshop both research teams arrived at an agreement with their respective schools to visit the schools again in the near future to see what, if any, effect the retraining session had teachers' efforts to implement active learning strategies. After expressing appreciation to our MIN Rukoh hosts as well as the participants from the two target schools, we closed the workshop late in the afternoon.

\section{Tentative Results of the Intervention}

The SD research team returned to the research site approximately two weeks after the retraining workshop. We were welcomed to the school by the principal before dividing our team into smaller groups to conduct classroom observations. To our surprise, we found teachers' instructional strategies and the classroom environment substantially improved. Each observer team reported that more instructional media, textbooks and posters were present in each classroom. Each classroom had received tool kits including attendance clocks, student records, reading and market corners. Students' desks were no longer arranged in rows but rather in small groups of four. In one of the classrooms the teacher had made available a copy of the English-language newspaper The Jakarta Post because, she said, students needed to know there were English-language magazines available in Indonesia.

Observers also noted that the teachers were trying to teach for active learning. One of the observers described a lesson in which students, working in groups of four, completed an assignment together. While a few students appeared to be passive, most were actively engaged with the assignment. While they were working, the teacher circulated around the classroom checking students' work and sometimes stopping to help them. When this teacher was asked about the substantial change in her classroom, she responded that after the retraining workshop she found it much easier to implement active learning strategies.

After the observations the research team met in the library, which had just been completed, for a final discussion with the principal, a few teachers, and two school supervisors. The research team expressed its satisfaction with the apparent changes in observed teaching practices. The supervisors agreed, though they noted that close monitoring was still necessary to support teachers and prevent a relapse into conventional transmission models of teaching. The principal expressed his opinion that the new teaching strategies they were working with were improving relations between teachers and students, and he invited the research team to visit the school again in the future.

\section{Conclusion}

The results of our action research project revealed a number of factors that were impeding teaching for active learning in this SD in Banda Aceh. Though teachers had attended training workshops on teaching for active learning, they did not have a clear understanding of the concept or did not retain what they had learned several months after the workshops. The principal and supervisors, who teachers seemed to look to for guidance, did not have a very clear understanding of teaching for active learning either, nor did they initially seem to be very committed to teaching for active learning. The confusion and lack of commitment was rounded out by the school committee, which did not see such reform in instructional strategies in the school as part of their responsibilities.

A one-day retraining workshop seemed to turn things around, however. While without on-going research we cannot be sure that the changes we saw were not simply a show put on for our benefit, our project suggests that three simple things may actually improve the odds of teaching for active learning catching on in elementary 
schools in Aceh. First, it seems important to come to a common conception of what it means to teach for active learning within a particular school. Everyone-teachers, principal, supervisorsneeds to be on the same page. Second, committed leadership is critical. While it is ultimately up to the teacher to change what he or she does in the classroom, the school leader must be committed to that change and communicate that commitment and his or her expectations to teachers. If teaching for active learning is not important to the principal, it is less likely to be important to the teachers. Finally, teachers may learn best from their peers. Seeing colleagues putting a change into effect in a similar setting is the strongest evidence teachers need that they, too, can do it.

In conclusion, while we cannot be sure that teaching for active learning will catch on and thrive in this school, it remains, at least, a possibility that has not yet been given up on. That, we believe, is a step in the right direction.

\section{Note}

1. Educational Unit Level Curriculum (KTSP: Kurikulum Tingkat Satuan Pendidikan) is a basic curriculum framework derived from the national curriculum for $\mathrm{K}-12$ for the purpose of providing guidance in the formulation of educational unit level curriculum and syllabus to each educational unit.

\section{References}

Australia-Indonesia Basic Education Program. 2010. Summary Report of AIBEP School and District Survey, 2009-2010. Canberra: Australian Agency for International Development. Available online at: www.ausaid.gov.au.

Bjork, Christopher. 2004. "Decentralization of Education, Institutional Culture and Teacher Autonomy in Indonesia." International Review of Education 50 (3/4): 245-262.

Bjork, Christopher. 2003. "Local Responses to Decentralization Policy in Indonesia." Comparative Education Review 47 (2): 184-216.

Bolhuis, Sanneke, and Marinus Voeten. 2001. "Toward SelfDirected Learning in Secondary Schools: What do Teachers Do?" Teaching and Teacher Education 17 (7): 837-855.

Chen, Yao-Jen, Tsen-Yung Wang, Shu-Fang Chen, and Rhi-Hua Liao. 2011. "StudentEngineers as Agents of Change: Combining Social Inclusion in the Professional Development of Electrical and Computer Engineering Students." Systematic Practice and Action Research 24 (3): 237-245.
Clover, Darlene. 2011. "Successes and Challenges of Feminist Arts-Based Participatory Methodologies with Homeless/Street-Involved Women in Victoria." Action Research 9 (1): 12-26.

de Baessa, Yetilú, Ray Chesterfield, and Tanya Ramos. 2002. "Active Learning and Democratic Behavior in Guatemalan Rural Primary Schools." Compare: A Journal of Comparative and International Education 32 (2): 205-218.

Dewey, John. 1938. Experience and Education. New York: The Free Press.

Digital Media Across Asia. 2011. Indonesia: Demographics. Seattle, WA: Wetpaint.com. Available online at: http://comm215.wetpaint.com.

Education Development Center (EDC). 2011. Decentralized Basic Education in Indonesia: Teaching and Learning. Washington, DC: EDC. Available online at: http://idd.edc.org.

Ginsburg, Mark B. and Nagwa M. Megahed. 2008. "Global Discourses and Educational Reform in Egypt: The Case of Active-Learning Pedagogies." Mediterranean Journal of Educational Studies 13(2): 91-115.

Halai, Nelofer. 2011. "How Teachers Become Action Researchers in Pakistan: Emerging Patterns from a Qualitative Metasynthesis." Educational Action Research 19 (2): 201-214.

Huebler, Friedrich. 2008. "Pupil/Teacher Ratio in Secondary School." International Education Statistics. Available online at: http://huebler.blogspot.com.

Index Mundi. 2011. Indonesia Literacy. Available online at: http://www.indexmundi.com.

Kemmis, S. and R. McTaggart. 2000. "Participatory Action Research.” In Handbook of Qualitative Research ed. N. K. Denzin \& Y. S. Lincoln. Thousand Oaks, CA: Sage.

Keyser, Marcia. 2000. "Active Learning and Cooperative Learning: Understanding the Difference and Using Both Styles Effectively." Research Strategies 17(1): $\quad 35-44$.

Kingsbury, Damien. 2006. Peace in Aceh: A Personal Account of the Helsinki Peace Process. Jakarta: Equinox Publishing.

López-Pastor, Victor M., Roberto Monjas, and Juan Carlos Manrique. 2011. "Fifteen Years of Action Research as Professional Development: Seeking More Collaborative, Useful and Democratic Systems for Teachers." Educational Action Research 19 (2): 153-170.

Mendenhall, Tai, Peter Harper, Heather Stephenson, and G. Santo Haas. 2010. "The SANTA Project (Students Against Nicotine and Tobacco Addiction): Using Participatory Research to Reduce Smoking in a High-Risk Young Adult Population.” Action Research 9 (2): 199-213.

Mullis, Ina V. S., Michael O. Martin, Eugenio J. Gonzales, and Steven J. Chrostowski. 2003. "International Student 
Achievement in Mathematics." In TIMSS 2003 International Mathematics Report, (pp. 31-54). Boston: TIMSS \& PIRLS International Study Center. Available online at: http://timss.bc.edu.

NationMaster.com. 2011. "Southeast Asia: Indonesia: Education." Available online at: http://nationmaster.com.

Ngwerume, Karebor Tuhaise, and Markus Themessl-Huber. 2010. "Using Action Research to Develop a Research Aware Community Pharmacy Team.” Action Research 8 (4): 387-406.

Niemi, Hannele. 2002. "Active Learning-A Cultural Change Needed in Teacher Education and Schools." Teaching and Teacher Education 18: 763-780.

Postholm, May Britt. 2011. "Teachers' Learning in a Research and Development Work Project." Educational Action Research 19 (2): 231-244.

Prince, Michael. 2004. "Does Active Learning Work? A Review of the Research." Journal of Engineering Education 93 (3): 223-231.

Rousseau, Jean-Jacques. 1762/1979. Emile. New York: Basic Books.

Setiawan, Raymond. 2009. "The Effectiveness of Teacher Training in Indonesia: A Practice by Sampoerna Foundation
Teacher Institute (SFTI).” Bonn: German Institute for Adult Education. Available online at: http://die-bonn.de.

Stern, David, and Günter Huber, eds. 1997. Active Learning for Students and Teachers: Reports from Eight Countries. New York: Peter Lang.

Stringer, Ernest. 2007. Action Research. 3rd ed. Thousand Oaks, CA: SAGE Publications.

Sturtevant, Elizabeth, and Wayne Linek. 2007. "Secondary Literacy Coaching: A Macedonian Perspective." Journal of Adolescent and Adult Literacy 51 (3): 240-250.

UNICEF. n. d. Indonesia: Overview-Education and Adolescent Development. Jakarta: UNICEF. Available online at: http://unicef.org.

United Nations Development Programme (UNDP) Philippines. 2005. Southeast Asia Human Development Report 2005. Philippine Institute for Development Studies. Available online at: http://dirp3.pids.gov.ph.

Woolman, David. 2002. "Lost Educational Opportunity: Can the First and Third Worlds Inform Each Other and Transfer Solutions?" Paper presented at the Comparative and International Education Society Annual Meeting, Orlando, FL, 6-9 March 2002. 